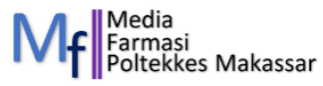

\title{
UJI AKTIVITAS EKSTRAK KULIT BUAH PISANG AMBON (Musa paradisiaca var. Savientum L.) TERHADAP PERTUMBUHAN Escherichia coli
}

\author{
Dwi Rachmawaty Daswi ${ }^{1 *}$, Alfrida M. Salasa ${ }^{1}$, Resti Miri ${ }^{1}$ \\ ${ }^{1}$ Jurusan Farmasi Poltekkes Kemenkes RI Makassar \\ *) E-mail korespondensi : dwialamsyah@gmail.com
}

DOI: https://doi.org/10.32382/mf.v13i2.830

ABSTRAK

Buah Pisang Ambon merupakan salah satu tanaman yang dapat digunakan sebagai bahan pembuatan obat tradisonal, namun kulitnya hanya menjadi limbah buangan di masyarakat. Kulit buah pisang ambon mengandung senyawa tannin dan flavonoid. Penelitian ini bertujuan untuk menentukan aktivitas ekstrak kulit buah pisang ambon terhadap pertumbuhan Escherichia coli. Kulit Buah Pisang Ambon yang diperoleh dari pasar Senggol Kota Makassar dikeringkan lalu di maserasi dengan pelarut etanol 96\%, kemudian diuapkan hingga diperoleh ekstrak kental. Selanjutnya dilakukan uji aktivitas dengan metode difusi agar. Hasil uji aktivitas menunjukkan diameter zona hambat rata-rata untuk konsentrasi $2 \%$ sebesar $12 \mathrm{~mm}$, konsentrasi $4 \%$ sebesar $16 \mathrm{~mm}$, dan pada konsentrasi $8 \%$ sebesar 19,33 mm, Kotrimoksazole sebagai kontrol positif sebesar $22 \mathrm{~mm}$ dan aquadest steril sebagai kontrol negatif tidak memperlihatkan adanya zona hambat. Hasil uji statistik Kruskal-Wallis $(\mathrm{p}<0,05)$ menunjukkan adanya perbedaan bermakna antar semua perlakuan. Maka dapat disimpulkan bahwa semua konsentrasi ekstrak Kulit Buah Pisang Ambon (Musa paradisiaca var. Savientum L.)memiliki aktivitas terhadap pertumbuhan Escherichia coli, dan aktivitas yang paling besar ditunjukkan oleh konsentrasi $8 \%$ walaupun aktivitasnya masih dibawah kontrol positif.

\section{Kata kunci : Kulit buah pisang ambon, ekstrak, aktivitas, Escherichia coli.}

\section{PENDAHULUAN}

Indonesia merupakan negara tropis dengan potensi tanaman yang secara turun temurun digunakan sebagai obat tradisional. Terdapatnya trend back to nature mengakibatkan masyarakat semakin menyadari pentingnya penggunaan bahan alami bagi kesehatan. Masyarakat semakin memahami keunggulan penggunaan obat tradisional, antara lain: harga yang lebih murah, kemudahan dalam memperoleh produk, dan mempunyai efek samping yang minimal (Murdopo, 2014).

Tumbuhan merupakan salah satu sumber obat-obatan yang diperlukan dalam dunia medis. Salah satu tanaman yang dapat dijadikan sebagai bahan pembuatan obatobatan tradisional adalah tanaman pisang. Indonesia merupakan salah satu negara yang memiliki keanekaragaman pisang sehingga menjadikannya sebagai salah satu negara pengekspor pisang. Seluruh bagian tanaman pisang dapat dimanfaatkan, mulai dari bonggol, batang, bunga, daun, dan buahnya. Kandungan gizi yang terdapat dalam setiap buah pisang matang adalah kalori, protein, lemak, karbohidrat, serat, kalsium, fosfor, besi, vitamin $\mathrm{A}$, vitamin $\mathrm{B}$, vitamin $\mathrm{C}$, dan air. Beberapa penelitian menyebut buah pisang bisa membantu mengatasi depresi, anemia, tekanan darah, sembelit, sakit jantung, gangguan saraf, dan mensuplai energi dalam otak (Chabuck, Z., Hindi, N. and Al-Charrakh, A.H. 2013).

Kulit buah pisang juga memiliki banyak manfaat namun belum banyak dimanfaatkan oleh masyarakat, bahkan kulit buah pisang hanya menjadi limbah buangan oleh masyarakat. Kulit buah pisang dapat meredakan nyeri pada luka bakar, mengatasi gatal pada kulit, mengobati kutil, diare, mempercepat penyembuhan luka yang sudah mulai kering, dan menyuburkan tanah (sebagai pupuk). Kulit buah pisang bahkan digunakan untuk memurnikan air dan menyaring logam berat, terutama timbal $(\mathrm{Pb})$ dan tembaga $(\mathrm{Cu})$ (Sopyan., 2012).

Penelitian yang dilakukan oleh Chabuck, Z., Hindi, N. and Al-Charrakh, A.H. (2013) menemukan bahwa ekstrak air kulit buah pisang yang segar dan berwarna kuning mampu menghambat pertumbuhan bakteri gram positif ( $S$ aureus dan $S$. pyogenes) dan gram negatif (M. catarrhalis, 
E.coli, dan K. pneumonia). Hal ini juga didukung oleh penelitian Ehiowemwenguan,G., Emoghene, A.O. and Inetianbor, J.E. (2014)yang menyatakan bahwa kulit buah pisang mengandung glikosida, alkaloid, saponin, tanin, dan flavonoid yang dapat menghambat bakteri pathogen.

Kulit pisang ambon (Musa Paradisiaca var. Savientum L.) juga dipercaya masyarakat dapat menyembuhkan berbagai penyakit infeksi, diantaranya diare oleh Escherichia coli. Kandungan fenolik dan bahan aktif lain seperti tanin dan flavonoid yang terkandung dalam kulit pisang ambon dapat dipertimbangkan sebagai antimikroba pilihan dalam mengatasi resistensi Escherichia coli terhadap antibiotik.

Penyakit diare adalah buang air besar dengan frekuensi yang tidak normal (meningkat) dalam konsistensi tinja yang lebih lembek atau cair. Keadaan yang harus dihindari oleh penderita diare adalah dehidrasi atau kekurangan cairan tubuh, karena jika hal tersebut terjadi dapat mengancam jiwa penderita apabila tidak segera diatasi .Escherichia coli merupakan $25 \%$ penyebab seluruh diare di negara sedang berkembang ( Jawetz, et al, 2005).

Berdasarkan uraian diatas maka akan dilakukan penelitian mengenai uji aktivitas ekstrak kulit buah pisang ambon terhadap pertumbuhan Escherichia coli.

Adapun tujuan dari penelitian ini adalah untuk menentukan aktivitas ekstrak Kulit Buah Pisang ambon (Musa paradisiaca var. Savientum L.) terhadap pertumbuhan Escherichia coli.

\section{METODE DAN BAHAN \\ Jenis Penelitian}

Jenis penelitian ini merupakan penelitian eksperimental laboratorium dengan melakukan serangkaian penelitian untuk mengamati dan menentukan aktivitas ekstrak Kulit Buah pisang ambon (Musa paradisiaca var. Savientum L.) terhadap pertumbuhan bakteri Escherichia coli.

\section{Waktu dan Tempat Penelitian}

Penelitian ini dilaksanakan pada bulan Maret tahun 2017, di Laboratorium Biologi Farmasi Jurusan Farmasi Politeknik Kesehatan Kementrian kesehatan RI Makasaar.

\section{Bahan uji dan sampel}

1. Bahan uji

Bahan uji pada penelitian ini adalah Kulit Buah pisang ambon yang telah dikeringkan dan diperoleh dari pas ar Senggol kota Makassar.

2. Sampel

Sampel dalam penelitian ini adalah kultur murni bakteri Escherichia coli yang berasal dari Laboratorium Biologi Farmasi Jurusan Farmasi Politeknik Kesehatan Kementrian Kesehatan RI Makassar.

\section{Alat dan Bahan yang Digunakan}

Alat yang digunakan dalam penelitian ini adalah sebagai berikut: bejana maserasi, autoklaf, cawan petri, corong, labu Erlenmeyer $250 \mathrm{ml}$, gelas kimia, gelas ukur $100 \mathrm{ml}$, inkubator, kapas, ose bulat, oven, spuit, dan rotavapor.

Bahan yang digunakan dalam penelitian ini adalah sebagai berikut: aquadest, kulit buah pisang ambon, kertas timbang, medium nutrient agar, etanol $96 \%$, kultur murni Escherichia coli, paper disc dan swab steril.

\section{Penyiapan bahan uji}

Kulit pisang ambon dibuat simplisia kering terlebih dahulu kemudian diekstraksi mengunakan metode maserasi menggunakan Etanol 96\% sehingga menghasilkan ekstrak kental.

\section{Penyiapan sampel}

Ekstrak kental diencerkan dengan aquadest steril. Pengenceran dilakukan sesuai dengan konsentrasi yang dibutuhkan yaitu sebesar $2 \%, 4 \%, 8 \%$, kontrol positif dan negatif.

\section{Pengujian daya hambat ekstrak etanol} Kulit Buah Pisang Ambon

Disiapkan medium NA steril lalu dituang secara aseptis kedalam cawan petri kurang lebih $20 \mathrm{ml}$ dan dibiarkan hingga memadat. Setelah itu dioleskan suspensi bakteri uji dengan menggunakan swab steril di atas media Nutrient Agar tersebut, diadaptasikan selama \pm 15 menit. Paper disc direndam didalam masing-masing konsentrasi ekstrak, aquadest dan didalam Kotrimoksazole selama \pm 15 menit. Selanjutnya paper disc diletakkan secara aseptis di atas permukaan medium Nutrient Agar dengan jarak yang 
lebih kurang sama dengan yang lain. Selanjutnya diinkubasi pada suhu $37^{\circ} \mathrm{C}$ selama 1x24 jam.

\section{Pengamatan dan Pengukuran Diameter Hambatan}

Pengamatan dan pengukuran diameter hambatan dilakukan dengan menggunakan jangka sorong setelah diinkubasi selama 1x24 jam.

\section{Pengumpulan dan Pengolahan Data}

Data yang dikumpulkan berupa hasil pengukuran diameter zona hambatan dengan menggunakan jangka sorong setelah diinkubasikan pada suhu $37^{\circ} \mathrm{C}$ selama $1 \times 24$ jam. Data kemudian diolah dengan menggunakan SPSS.

\section{HASIL DAN PEMBAHASAN \\ Hasil penelitian}

Hasil uji aktivitas ekstrak Kulit Buah pisang ambon (Musa paradisiaca var. Savientum L.) terhadap pertumbuhan Escherichia coli yang dilakukan dengan metode difusi agar dan diperoleh zona hambat sebagai berikut

Tabel.1 : Hasil pengukuran diameter zona hambatan uji aktivitas ekstrak Kulit Buah pisang ambon (Musa paradisiaca var. Savientum L.) terhadap pertumbuhan Escherichia coli.

\begin{tabular}{cccccc}
\hline \multirow{2}{*}{ Replikasi } & \multicolumn{5}{c}{ Diameter Zona Hambat (mm) } \\
\cline { 2 - 5 } & Kontrol (-) & Konsentrasi $2 \%$ & Konsentrasi 4\% & Konsentrasi 8\% & Kontrol (+) \\
\hline I & 0 & $9 \mathrm{~mm}$ & $17 \mathrm{~mm}$ & $19 \mathrm{~mm}$ & $22 \mathrm{~mm}$ \\
II & 0 & $12 \mathrm{~mm}$ & $14 \mathrm{~mm}$ & $19 \mathrm{~mm}$ & $21 \mathrm{~mm}$ \\
III & 0 & $15 \mathrm{~mm}$ & $17 \mathrm{~mm}$ & $20 \mathrm{~mm}$ & $23 \mathrm{~mm}$ \\
\hline Total & 0 & $36 \mathrm{~mm}$ & $48 \mathrm{~mm}$ & $58 \mathrm{~mm}$ & $66 \mathrm{~mm}$ \\
\hline Rata-rata & 0 & $12 \mathrm{~mm}$ & $16 \mathrm{~mm}$ & $19.33 \mathrm{~mm}$ & $22 \mathrm{~mm}$ \\
\hline
\end{tabular}

Sumber : Data Primer 31 Maret 2017

\section{Pembahasan}

Penelitian yang telah dilakukan di Laboratorium Biologi Farmasi Jurusan Farmasi Politeknik Kesehatan Kementrian Kesehatan RI Makassar ini bertujuan untuk menentukan aktivitas ekstrak Kulit Buah pisang ambon (Musa paradisiaca var. Savientum L.) terhadap pertumbuhan Escherichia coli.

Pada penelitian ini metode yang digunakan adalah difusi agar dengan menggunakan paper disc, yang diletakkan pada medium Nutrient Agar (NA) yang kemudian diisi dengan masing-masing konsentrasi $(2 \%, 4 \%$, dan $8 \%)$ ekstrak Kulit Buah pisang ambon (Musa paradisiaca var. Savientum L.) larutan kotrimoksazol sebagai kontrol positif dan aquadest sebagai kontrol negatif. Metode ini dilakukan untuk mengetahui besarnya diameter zona hambat yang terbentuk terhadap Escherichia coli, setelah masa inkubasi 24 jam, zat aktif yang terdapat dalam paper disc akan berdifusi keluar untuk menghambat pertumbuhan Escherichia coli pada medium NA yang ditunjukkan dengan adanya zona hambat yang terbentuk pada medium yang ditandai dengan adanya daerah bening/transparan disekeliling paper disc, zona hambat yang terbentuk inilah yang kemudian diukur diameternya.

Dari hasil penelitian yang diperoleh bahwa ekstrak Kulit Buah pisang ambon (Musa paradisiaca var. Savientum L.) menghasilkan masing-masing diameter zona hambatan yang signifikan terhadap bakteri Escherichia coli, dimana rata-rata zona hambat yang diperoleh yaitu berbeda, untuk konsentrasi $2 \%$ sebesar $12 \mathrm{~mm}$, konsentrasi $4 \%$ sebesar $16 \mathrm{~mm}$, konsentrasi $8 \%$ sebesar $19,33 \mathrm{~mm}$ dan pembanding kontrol positif kotrimoksazol sebesar $22 \mathrm{~mm}$, sedangkan pembanding kontrol negatif aquadest steril tidak memperlihatkan adanya zona hambatan 
disekitar paper disc. Jadi semakin besar konsentrasi yang digunakan dari ekstrak Kulit Buah pisang ambon (Musa paradisiaca var. Savientum L.) maka semakin besar zona hambatan yang dihasilkan.

Bahan uji yang digunakan dalam penelitian ini adalah Kulit Buah pisang ambon (Musa paradisiaca var. Savientum L.) yang telah dikeringkan. Proses penarikan zat aktif yang terkandung didalamnya dilakukan dengan metode maserasi, karena metode tersebut merupakan salah satu metode umum dalam proses ekstraksi bahan alam, selain itu metode maserasi lebih sederhana dan mudah. Pelarut yang digunakan dalam proses ekstraksi adalah etanol $96 \%$ karena etanol dapat menarik zat aktif baik yang bersifat polar maupun non polar, universal dan mudah didapat. Selain itu senyawa tanin dan flavonoid yang terkandung dalam Kulit Buah pisang ambon (Musa paradisiaca var. Savientum L.) bersifat polar sehingga mudah terekstraksi menggunakan pelarut etanol 96\%. Mekanisme tanin dalam dalam menghambat pertumbuhan Escherichia coli adalah menghambat sintesis protein, adhesin, dan enzim reverse transcriptase dan DNA topoisomerase, sedangkan mekanisme dari flavonoid adalah menurunkan kekentalan membran, menghambat metabolisme dan mengubah sifat fisik dan kimiawi sitoplasma yang mengandung protein dan mendenaturasi dinding sel bakteri dengan cara berikatan dengan protein melalui ikatan hidrogen, aktifitas ini akan mengganggu fungsi permeabilitias selektif, fungsi pengangkutan aktif, dan pengendalian susunan protein. Seluruh mekanisme tersebut akan menyebabkan terhambatnya pertumbuhan bakteri Escherichia coli.

Uji statistik test of normality dilakukan untuk melihat normalitas dari masing-masing perlakuan dimana hasil yang diperoleh hanya pada perlakuan konsentrasi 4\% dan konsentrasi $8 \%$ saja yang signifikan atau menunjukkan adanya perbedaan pada taraf $\alpha=0,05$, sehingga hasil yang diperoleh tidak normal. Pada pengolahan data hasil statistik test of homogeneity of variences untuk melihat homogenitas sampel dimana hasil yang diperoleh adalah 0,109 pada taraf $\alpha=0,05$, sehingga hasil yang diperoleh homogen.

Berdasarkan dari hasil tes tersebut diperoleh data yang homogen namun tidak normal, maka uji tidak dapat dilakukan untuk uji One Way Anova tetapi dilanjutkan dengan uji nonparametric Kruskal-wallis test untuk melihat perbedaan antar semua perlakuan dan hasil yang diperoleh yaitu p: $0,01<0,05$, menunjukkan bahwa terdapat perbedaan antar semua perlakuan, sehingga dilanjutkan dengan uji Mann-Whitney untuk melihat perbedaan antar perlakuan. Dari hasil uji Mann-Whitney menunjukkan bahwa konsentrasi $2 \%$ dan $4 \%$ memiliki aktivitas yang sama $(p>0,05)$ dan konsentrasi $8 \%$ memliki aktivitas yang lebih besar dibandingkan dengan konsentrasi $2 \%$ dan $4 \%$ $(\mathrm{p}<0,05)$, tetapi tidak memiliki aktivitas yang lebih besar dari kontrol positif.

Perbandingan efek pada konsentrasi tertentu dalam penelitian ini menunjukkan bahwa semua konsentrasi ekstrak memiliki aktivitas terhadap pertumbuhan Escherichia coli dan aktivitas yang paling besar ditunjukkan oleh konsentrasi $8 \%$ walaupun aktivitasnya masih dibawah kontrol positif. Oleh karena itu semakin tinggi konsentrasi ektstrak Kulit Buah pisang ambon (Musa paradisiaca var. Savientum L.) maka semakin besar aktivitasnya dalam menghambat pertumbuhan Escherichia coli.

\section{PENUTUP}

\section{Kesimpulan}

Berdasarkan hasil penelitian, analisis data dan pembahasan yang telah dilakukan terhadap uji aktivitas ekstrak Kulit Buah pisang ambon (Musa paradisiaca var. Savientum L.) terhadap pertumbuhan Escherichia coli diperoleh diameter hambatan rata-rata untuk konsentrasi $2 \%$ sebesar $12 \mathrm{~mm}$, konsentrasi $4 \%$ sebesar 16 mm, konsentrasi $8 \%$ sebesar $19.33 \mathrm{~mm}$ dan untuk kontrol positif (Kotrimoksazol) sebesar $22 \mathrm{~mm}$ sedangkan untuk kontrol negatif (aquadest steril) tidak memperlihatkan adanya zona hambatan. Hasil uji statisik Kruskal-Wallis $\quad(\mathrm{p}<0,05) \quad$ menunjukkan adanya perbedaan bermakna antar semua perlakuan. Maka dapat disimpulkan bahwa semua konsentrasi ekstrak Kulit Buah pisang ambon (Musa paradisiaca var. Savientum L.) memiliki aktivitas terhadap pertumbuhan Escherichia coli, dan aktivitas yang paling besar ditunjukkan oleh konsentrasi $8 \%$ walaupun aktivitasnya masih dibawah kontrol positif. Hal ini menunjukkan bahwa semakin tinggi konsentrasi ekstrak Kulit 
Buah pisang ambon(Musa paradisiaca var. Savientum L.) maka semakin besar pula aktivitasnya

dalammenghambat pertumbuhan Escherichi a coli.

\section{Saran}

Berdasarkan hasil penelitian yang dilakukan, maka disarankan untuk penelitian lebih lanjut tentang uji aktivitas ekstrak Kulit Buah pisang ambon (Musa paradisiaca var. Savientum L.) dengan menggunakan mikroorganisme lain

\section{DAFTAR PUSTAKA}

Cahyono, B., (2009). Pisang: Usaha Tani dan Penanganan Pasca Panen. Yogyakarta: Kanisius.

Chabuck, Z., Hindi, N. and Al-Charrakh, A.H. (2013). "Antimicrobial Effect of Aqueous Banana Extract”. Research Gate: Pharmaceutical Sciences. 7375.

Compean, K.L. and Ynalvez, R.A. (2014). "Antimicrobiual Activity of Plant Secondary Metabolites". A Review, Research of Medical Plant. 1-10.

Cushnie, T.P. and Lamb A.J. (2005). "Antimicrobial Activity of Flavonoids" International Journal of Antimicrobial Agents. (26), 343-356.

Ehiowemwenguan, G., Emoghene, A.O. and Inetianbor, J.E. (2014). "Antibacterial and Phytochemical Analysis of Banana Fruit Peel". ISQR Journey of Pharmacy. (4), 18-25.

Fardiaz, S. (1992). Mikrobiologi Pangan I. Jakarta: Gramedia Pustaka Utama.

Jawetz, et al. (2005). Mikrobiologi Kedokteran Jawetz, Melnick, \& Adelberg. Translation of Jawetz, Melnick, and Adelberg's Medical Microbiology, 23thEd, Alih bahasa Hartanto, H., dkk. Jakarta: EGC.

Kumar, K.P.S. et al. (2012). "Traditional and Medical Uses of Banana". Journal of Pharmacognosy and Phytochemistry. 1, (3), 51-63.

Lino, P.B. et al. (2011). "Evaluation of PostSurgical Healing In Rats Using A Topical Preparation Based On Extract of Musa sapientum Epicarp". Revista Brasileira de Farmacognosa. (21), 491-496.

Min, B.R. et al. (2008). "Comparative Antimicrobial Activity of Tannin Extract From Perennial Plants on Mastitis Pathogens". Scientific Research and Essay. 3, (2),66-73.

Murdopo, (2014). Obat Herbal Tradisional. Jakarta: Ditjen Kementrian Perdagangan Republik Indonesia.

Pelczar, M.J. dan Chan, E.C.S. (2007). Dasar-dasar Mikrobiologi. Terjemahan Elements of Microbiology (edisi 1). Jakarta: UI Press.

Simatupang, M. (2006). Morfologi, Struktur, Fisiologi dan Metabolisme Bakteri. Medan: Departemen Mikrobiologi Universitas Sumatera Utara.

Soegijanto, Soegeng. (2002). Ilmu Penyakit Anak "Diagnosa dan Penatalaksanaan". Jakarta: Salemba Medika

Sopyan, D.I. (2012). Benar-Benar Unik Tapi Nyata. Jakarta: Pusindo.

Supardi dan Sukamto. (1999). Mikrobiologi Dalam Pengolahan Dan Keamanan Produk Pangan. Bandung: Penerbit Alumni.

Suyanti dan Supriyadi, A. (2008). Pisang; Budidaya, Pengolahan, dan Prospek Pasar. Jakarta: Penebar Swadaya. 